\title{
Establishing consensus on emergency department interventions that could be conducted in sub-acute care settings for non-emergent paramedic transported visits: A RAND/UCLA modified Delphi study
}

\author{
Authors: \\ Ryan P Strum, BSc BA PCP \\ Walter Tavares, $\mathrm{PhD}$ \\ Andrew Worster, MD, MSc \\ Lauren E Griffith, PhD \\ Andrew P Costa, PhD
}

\section{Author Affiliations:}

RPS, AW, LEG, APC: Department of Health Research Methods, Evidence and Impact, McMaster University, Hamilton, Canada

WT: The Wilson Centre, University of Toronto, Toronto, Canada

WT: York Region Paramedic and Senior Services, Regional Municipality of York, Newmarket, Canada

LEG: McMaster Institute for Research and Aging, McMaster University, Hamilton, Canada

AW: Department of Medicine, Division of Emergency Medicine, McMaster University, Hamilton, Canada

APC: Department of Medicine, McMaster University, Hamilton, Canada

\section{Corresponding Author:}

Ryan P Strum

McMaster University

CRL B106

1280 Main Street West

Hamilton, ON, L8S 4L8

Strumr@mcmaster.ca

\section{Funding Statement:}

The investigators received no specific funding for this study.

\section{Declaration of Competing Interests:}

All authors of this manuscript do not declare any competing interests, financial or otherwise.

\section{Word Count:}

Abstract: 268

Introduction: 355

Interpretation: 795

Manuscript: 2,925 


\begin{abstract}

\section{Background}

Patients transported by paramedics for non-emergent conditions are increasing in Ontario and contribute to an emergency department (ED) crisis. Redirecting certain patients to sub-acute healthcare may be beneficial and suitable. We examined if ED interventions conducted on nonemergent paramedic transported patients could be conducted in sub-acute health centres.
\end{abstract}

\title{
Methods
}

A RAND/UCLA modified Delphi study was conducted. Twenty emergency and primary care physicians rated the suitability of the 150 most frequently recorded interventions for completion in sub-acute healthcare centres and provided comments to augment ratings. Interventions were performed on non-emergent adult patients transported by paramedics to an ED, and abstracted from the National Ambulatory Care Reporting System database (January 1, 2014 to March 31, 2018). We used two rounds of a modified Delphi process and set consensus at $70 \%$ agreement.

\section{Results}

Consensus was reached on $146(97.3 \%)$ interventions; 103 interventions (68.7\%) were suitable for sub-acute centres, 43 (28.7\%) for ED only; 4 (2.6\%) did not receive consensus. For sub-acute centres, all 103 interventions were rated for urgent care centres; walk-in medical centres were applicable for 46 (30.6\%) and nurse practitioner-led clinics for 47 (31.3). Diagnostic imaging availability, physician preferences and staffing were determining factors for discrepancies in subacute centre ratings.

\section{Interpretation}

The majority of included ED interventions performed on non-emergent patients transported by paramedics were identified as suitable for urgent care clinics, with one-third being suitable for either walk-in medical centres or nurse practitioner-led clinics. In combination with additional patient details and supports, knowledge of interventions suitable for sub-acute healthcare centres will inform a patient classification model for paramedic-initiated redirection of patients from ED.

\section{Study registration: ID ISRCTN22901977.}


medRxiv preprint doi: https://doi.org/10.1101/2021.06.01.21258191; this version posted June 4, 2021. The copyright holder for this preprint (which was not certified by peer review) is the author/funder, who has granted medRxiv a license to display the preprint in perpetuity.

It is made available under a CC-BY 4.0 International license.

\section{BACKGROUND}

Paramedic services are increasingly transporting patients with non-emergent conditions to the emergency department (ED) when primary healthcare facilities may be more beneficial for their care. $(1,2)$ In Ontario, patients with non-emergent conditions account for $60 \%$ of all ambulance transported patients, of which $74 \%$ are discharged the same day.(3) Initiatives in health policy and research have not decreased paramedic transports for non-emergent ED visits; from 2014 to 2017 usage has increased by 12\% (456 510 / 511 801) in Ontario.(4) Increasing ED visits have outpaced population growth in Ontario by more than double (13.6\%, vs. $6.2 \%$ respectively)(5), suggesting utilization of ED's has broadened. Broadened use of paramedic services by non-emergent patients and a legislative requirement to transport all patients to the ED regardless of acuity is exacerbating the problem. $(6,7)$

Redirecting non-emergent patients to sub-acute care centres instead of EDs may offer a feasible solution to prevent some non-emergent patient visits.(8) Patient redirection has been successful in Canada; a computer algorithm to direct non-emergent visits from ED to primary care centres not only left patients as satisfied with the care they received (84\%), but was also described as a safe strategy (5.9\% of 980 diverted patients had unexpected healthcare visits to the ED; none for severe complication).(9) Internationally, sub-acute centres such as urgent care clinics have reduced the likelihood of ED visits for lower acuity conditions, have shown that they can perform treatments equivalent to EDs for minor illnesses and traumatic injuries, and at a lower cost.(10-13) Redirection to sub-acute care centres by paramedics may have beneficial long-term implications by reducing paramedic transport consumption and can have higher cost effectiveness than transport to an acute centre ED.(14-17) 
medRxiv preprint doi: https://doi.org/10.1101/2021.06.01.21258191; this version posted June 4, 2021. The copyright holder for this preprint (which was not certified by peer review) is the author/funder, who has granted medRxiv a license to display the preprint in perpetuity.

It is made available under a CC-BY 4.0 International license.

Evidence to support redirecting patients transported by paramedics to sub-acute centres is inconclusive, and international findings may not be generalizable across Canada.(18) Part of the difficulty arises from an absence of a suitable patient classification for examining which patients transported by paramedic services could have been potentially redirected.(17) Therefore, the objective of this study was to establish consensus on a set of ED interventions performed on nonemergent patients transported by paramedics that could be conducted in sub-acute healthcare centres.

\section{METHODS}

We used a three-stage RAND/UCLA modified Delphi study design to evaluate consensus on ED physician interventions that could be conducted in alternative sub-acute health centres. This methodology allowed us to assess a collective groups judgements on patient procedures and facilitate group discussion between rounds.(19) The CHERRIES reporting guideline was followed to report this study.(20)

\section{Stage 1: Identifying ED inventions to include in the RAND/UCLA modified Delphi}

We generated a list of unique Canadian Classification for Health Interventions (CCI) main intervention codes recorded on non-emergent adult patients (18 years or greater) that were transported to hospital by paramedics in Ontario from January 1, 2014 to March 31, 2018 from the National Ambulatory Care Reporting System (NACRS) ED database. NACRS contains an Ontario population-level collection of hospital administrative records. Non-emergent patients were considered to have a Canadian Triage and Acuity Score (CTAS) of three (urgent) to five (non-urgent), and were assigned their score upon entry to the ED by an ED or triage nurse. 
medRxiv preprint doi: https://doi.org/10.1101/2021.06.01.21258191; this version posted June 4, 2021. The copyright holder for this preprint (which was not certified by peer review) is the author/funder, who has granted medRxiv a license to display the preprint in perpetuity.

It is made available under a CC-BY 4.0 International license.

CTAS is an ordinal scale that ranges from one to five, with a score of one representing the most emergent (resuscitation) and five as least urgent (non-urgent). We determined a priori that our intervention list for the modified Delphi exercise should encompass at least $95 \%$ of total interventions in the study cohort to increase face validity.

\section{Stage 2: Selection of experts to constitute the Delphi expert committee}

We used purposive sampling to select 25 primary care and emergency physicians who were currently or recently practicing in Ontario, Canada.(3) We sought physicians who had either extensive medical experience, academic experience, or a leadership role in paramedic practice oversight to ensure they could offer high quality comprehension when evaluating ED interventions. All selected experts were sent a study information package (objective, purpose, contribution), and those who participated gave informed consent prior to beginning the modified Delphi. We only included physicians as all interventions were performed by a physician. All other types of practitioners (including paramedics) were excluded to reduce any potential bias of experts evaluating interventions that may not be within the practitioner's scope of practice. We determined a priori the Delphi expert committee must be composed of at least ten physicians, with representation from both emergency and primary care disciplines to increase the reliability of group judgements.(21) Once an expert was recruited, they were asked to complete a demographic questionnaire. Only physicians who completed at least one round would be included in the Delphi expert committee, and were provided a $\$ 75$ e-gift card for participation.

\section{Stage 3: Exploring consensus on ED interventions that could be conducted in sub-acute health care centres}


medRxiv preprint doi: https://doi.org/10.1101/2021.06.01.21258191; this version posted June 4, 2021. The copyright holder for this preprint (which was not certified by peer review) is the author/funder, who has granted medRxiv a license to display the preprint in perpetuity.

It is made available under a CC-BY 4.0 International license.

We used the RAND/UCLA modified Delphi technique to assess expert consensus through two rounds of ratings over an eight-week timeframe.(3) The modified Delphi method is a strategy that analyzes collective expert judgements to produce superior results than any one expert would, resulting in increased content validity.(22) We used a secure and encrypted CheckMarket software program to develop and administer the study questionnaires to experts. All data were stored on the investigators in encrypted servers. Round 1 of the modified Delphi included all ED interventions identified in Stage 1. Interventions were presented in six subsections based on their section of the CCI Tabular List, 2018 Volume 3 categorization: (1) physical/physiological therapeutic interventions; (2) diagnostic interventions; (3) diagnostic imaging interventions, and; (6) cognitive, psychosocial and sensory therapeutic interventions, (7) other healthcare interventions, and (8) therapeutic interventions strengthening the immune system.(23) Section (5) obstetrical and fetal interventions were not included as no interventions assigned in this section was identified in the cohort, and no randomization of questions were used. For each intervention, experts were asked to rate whether the intervention should be conducted exclusively in the ED, or alternatively, if could be conducted in a sub-acute healthcare centre. If an expert indicated an intervention suitable for a sub-acute centre, they were asked if it could be conducted in a: (1) urgent care centre, (2) walk-in medical centres, and (3) nurse practitioner led-clinics (multiple selections were permitted). These sub-acute centres were selected as they represented the most feasible centres patients could be redirected to when transported by paramedic services, their services target non-emergent events, are abundant in Ontario, and at present do not receive patients by ambulance. Standardized definitions of each destination were provided to minimize any heterogeneity in expert interpretation of a healthcare centres function. Additionally, descriptions of each healthcare centres staffing, imaging and non- 
medRxiv preprint doi: https://doi.org/10.1101/2021.06.01.21258191; this version posted June 4, 2021. The copyright holder for this preprint (which was not certified by peer review) is the author/funder, who has granted medRxiv a license to display the preprint in perpetuity.

It is made available under a CC-BY 4.0 International license.

clinical specialty service abilities were provided to increase inter-member consistency. Experts were provided a free-text comment space for each intervention to support their decision.

We determined consensus as any intervention receiving $70 \%$ or greater agreement amongst all experts for an individual health care centre (either ED or sub-acute centre). We collected all expert ratings from Round 1, extracted the data of individual reports and composed a general feedback form that contained aggregate percent agreement of all interventions reaching consensus, and those that did not. We hosted a videoconference debrief with the Delphi expert committee to share the results of Round 1, and to facilitate a discussion on the interventions that did not reach consensus.(19) We examined the comments of Round 1 for justifications of expert decisions, and to amend any framing of interventions that may have been unclear in Round 1 for Round 2. Experts were able to login to their questionnaire with their name, change their answers, and could not submit a second questionnaire to avoid duplication.

Round 2 of the modified Delphi included all ED interventions that did not receive consensus in Round 1. Expert ratings of Round 2 would serve as the final consensus level on the residual interventions.

\section{RESULTS}

We identified 150 of the most frequently recorded Canadian Classification for Health Interventions conducted on non-emergent patients transported by paramedic services to an ED using the NACRS database. These interventions represented 95.5\% (1 239 998/1 319 388) of all interventions recorded in this NACRS cohort of Ontario ED patients in the study period. All 150 interventions were included in Round 1 of the RAND/UCLA modified Delphi exercise, the majority of interventions belonging to CCI sections 1, 2 and 3 (137 / 150; 91.3\%). 
medRxiv preprint doi: https://doi.org/10.1101/2021.06.01.21258191; this version posted June 4, 2021. The copyright holder for this preprint (which was not certified by peer review) is the author/funder, who has granted medRxiv a license to display the preprint in perpetuity.

It is made available under a CC-BY 4.0 International license.

A total of 25 physicians who met the selection criteria were invited to participate by email, 21 accepted and consented to participate. Collectively 20 experts completed Round 1 and constituted the Delphi expert committee for this study, and completed $100 \%$ of each questionnaire. Experts were recruited from October 13 to November 5, 2020, and the modified Delphi consensus rounds occurred between November 6 and December 19, 2020. Figure 1 shows the flow of recruitment and modified Delphi Rounds in the study.

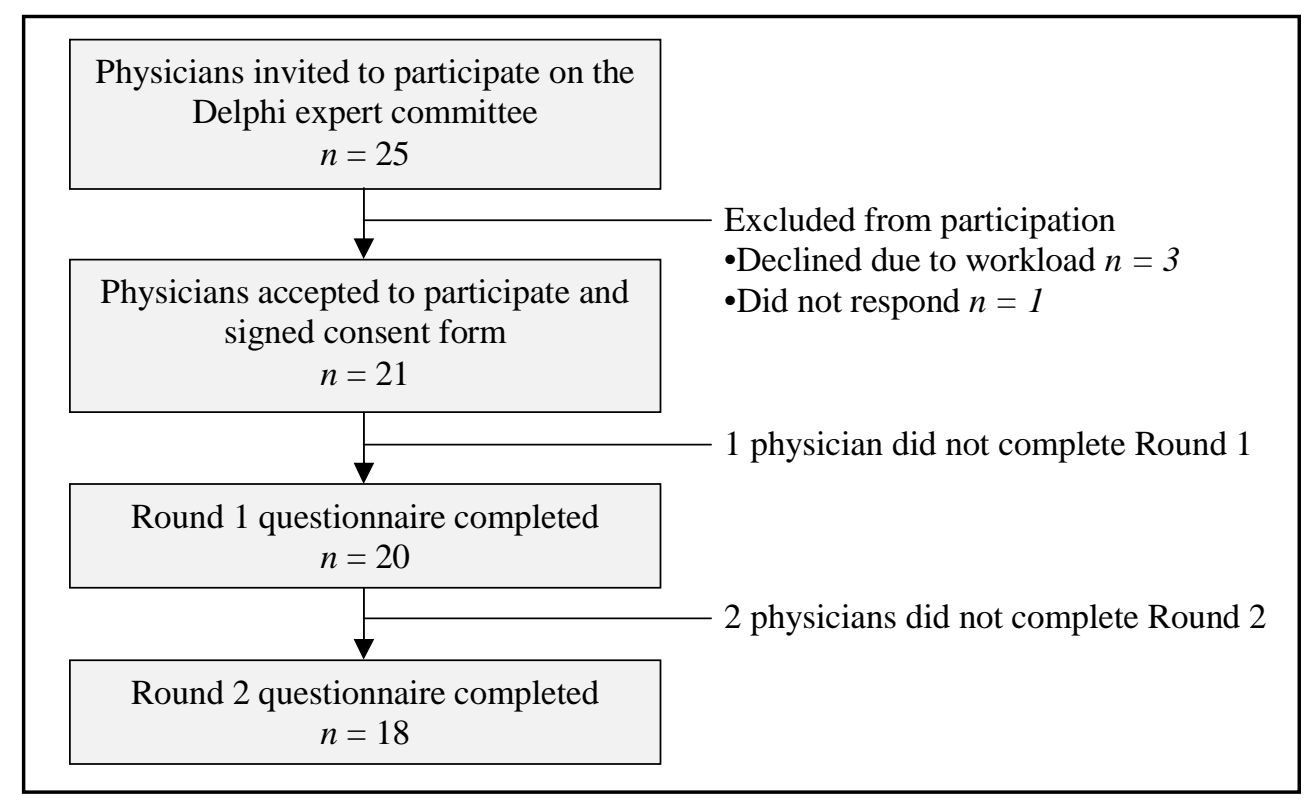

Figure 1: Study course of recruitment and 2 rounds of the RAND/UCLA modified Delphi consensus exercise.

The majority of experts were male $(70 \%)$ and reported their primary medical practice as emergency medicine (80\%), with the remaining as family medicine $(15 \%)$ or both $(5 \%)$. The characteristics of the Delphi expert committee are shown in Table 1.

Table 1: Demographic characteristics of the Delphi expert committee in the RAND/UCLA modified Delphi consensus exercise. 


\begin{tabular}{|lc|}
\hline Characteristic & $\begin{array}{c}\text { Experts, } \boldsymbol{n = 2 0} \\
(\boldsymbol{n}, \boldsymbol{\%})\end{array}$ \\
\hline Gender & $14(70 \%)$ \\
Male & $6(30 \%)$ \\
Female & \\
Province of practice (present) & $18(90 \%)$ \\
Ontario & $2(10 \%)$ \\
Quebec & \\
Primary medical practice & $16(80 \%)$ \\
Emergency medicine & $3(15 \%)$ \\
Family medicine & $1(5 \%)$ \\
Both & \\
Length of practice, yrs & $2(10 \%)$ \\
0 to 4 & $5(25 \%)$ \\
5 to 9 & $2(10 \%)$ \\
10 to 14 & $2(10 \%)$ \\
15 to 19 & $2(10 \%)$ \\
20 to 24 & $2(10 \%)$ \\
25 to 29 & $5(25 \%)$ \\
30 or greater & \\
Medical director, Ontario & $5(25 \%)$ \\
paramedic practices &
\end{tabular}

In Round 1, 139 interventions achieved a 70\% consensus agreement amongst all experts $(92.7 \%)$ for use in at least a single sub-acute healthcare centre. All interventions included in Round 1 were considered and rated by all 20 participating experts. The remaining 11 interventions which did not achieve consensus were included in Round 2, of which all were CCI section 1 interventions (i.e., physical/physiological therapeutic interventions). In Round 2, seven additional interventions reached consensus from experts for use in at least a single sub-acute healthcare centre, with the remaining four not reaching consensus in this study. Two of the experts that complete Round 1 did not complete round 2. Consensus results in the RAND/UCLA modified Delphi exercise are shown in summary by round and healthcare centre in Table 2 . 
Table 2: Emergency department interventions receiving consensus through each round of the RAND/UCLA modified Delphi, and final results of healthcare centre that could conduct the intervention.

\begin{tabular}{|c|c|c|c|c|c|c|c|c|c|c|}
\hline \multirow{2}{*}{$\begin{array}{l}\text { Canadian Classification for } \\
\text { Health Interventions } \\
\text { Section }^{\text {a }}\end{array}$} & \multicolumn{2}{|c|}{ Round 1} & \multicolumn{2}{|c|}{ Round 2} & \multicolumn{2}{|c|}{ Cumulative Results } & \multirow{2}{*}{$\begin{array}{c}\text { Acute Centre } \\
\text { ED, } n\end{array}$} & \multicolumn{3}{|c|}{ Sub-Acute Centres } \\
\hline & Int, $n$ & Cons, $n(\%)$ & Int, $n$ & Cons, $n(\%)$ & Cons, $n(\%)$ & No Cons, $n$ & & $\mathrm{UCC}, n$ & WM Centre, $n$ & NP Clinic, $n$ \\
\hline $\begin{array}{l}\text { 1 - Physical / Physiological } \\
\text { Therapeutic }\end{array}$ & 56 & $45(80.4)$ & 11 & $7(63.6)$ & $52(92.9)$ & 4 & 10 & 42 & 27 & 29 \\
\hline 2 - Diagnostic & 8 & $8(100)$ & - & - & $8(100)$ & 0 & 1 & 7 & 6 & 6 \\
\hline 3 - Diagnostic Imaging & 73 & $73(100)$ & - & - & $73(100)$ & 0 & 32 & 41 & 0 & 0 \\
\hline $\begin{array}{l}\text { 6- Cognitive, Psychosocial } \\
\text { and Sensory Therapeutic }\end{array}$ & 11 & $11(100)$ & - & - & $11(100)$ & 0 & 0 & 11 & 11 & 10 \\
\hline 7 - Other Healthcare & 1 & $1(100)$ & - & - & $1(100)$ & 0 & 0 & 1 & 1 & 1 \\
\hline $\begin{array}{l}8 \text { - Therapeutic Interventions } \\
\text { Strengthening the Immune } \\
\text { System }\end{array}$ & 1 & $1(100)$ & - & - & $1(100)$ & 0 & 0 & 1 & 1 & 1 \\
\hline
\end{tabular}


medRxiv preprint doi: https://doi.org/10.1101/2021.06.01.21258191; this version posted June 4, 2021. The copyright holder for this preprint (which was not certified by peer review) is the author/funder, who has granted medRxiv a license to display the preprint in perpetuity.

It is made available under a CC-BY 4.0 International license .

Of ED interventions that achieved overall consensus, $103(68.7 \%)$ were rated from experts for their suitability for a sub-acute healthcare centre. Of the 47 remaining, 43 interventions $(28.7 \%$ ) were rated as only appropriate for the ED, and four interventions did not reach consensus (2.6\%). All 103 intervention were deemed suitable for an urgent care centre, of which 46 interventions were suitable for a walk-in medical centre, and 47 for a nurse practitioner-led clinic. Of interventions requiring diagnostic imaging (Section 3), all magnetic resonance imaging (MRI) or computed tomography (CT) imaging were identified as only suitable for the ED, while the remaining two imaging categories (x-ray, ultrasound) were all rated appropriate for urgent care centres. All interventions of CCI Sections 6, 7 and 8 were determined to be appropriate for sub-acute healthcare centres, and nearly all inventions of Section 2. The four interventions that did not receive consensus ranged in rating of 50-66\% amongst expert agreement. All interventions receiving consensus for any of the three sub-acute healthcare centres are shown in Table 3, and results of the RAND/UCLA modified Delphi agreement ratings for all interventions are shown in Table 4 (Appendix).

Table 3: Emergency department interventions on non-emergent paramedic transported patients deemed suitable for sub-acute healthcare centres, shown by care centre.

\begin{tabular}{|c|c|c|c|c|}
\hline \multicolumn{5}{|c|}{ Canadian Classification for Health Interventions } \\
\hline Section & Intervention & $\begin{array}{l}\text { Urgent Care } \\
\text { Centre, } \\
n=103\end{array}$ & $\begin{array}{c}\text { Walk-In } \\
\text { Medical } \\
\text { Centre, } \\
n=46\end{array}$ & $\begin{array}{c}\text { Nurse } \\
\text { Practitioner- } \\
\text { Led Clinic, } \\
n=47\end{array}$ \\
\hline \multirow{5}{*}{$\begin{array}{l}\text { (1) Physical/ } \\
\text { Physiological } \\
\text { Therapeutic } \\
\text { Interventions }\end{array}$} & $\begin{array}{l}\text { Control of bleeding, nose using per orifice approach and } \\
\text { agent NEC [e.g. silver nitrate] }\end{array}$ & $\sqrt{ }$ & $\sqrt{ }$ & $\sqrt{ }$ \\
\hline & $\begin{array}{l}\text { Control of bleeding, nose using per orifice approach and } \\
\text { device NEC (e.g. electrocautery) }\end{array}$ & $\sqrt{ }$ & & \\
\hline & $\begin{array}{l}\text { Control of bleeding, nose using per orifice approach and } \\
\text { packing }\end{array}$ & $\sqrt{ }$ & & \\
\hline & $\begin{array}{l}\text { Drainage, bladder using per orifice approach and drainage } \\
\text { catheter }\end{array}$ & $\sqrt{ }$ & $\sqrt{ }$ & \\
\hline & $\begin{array}{l}\text { Extraction, rectum using per orifice approach and manual } \\
\text { technique }\end{array}$ & $\sqrt{ }$ & $\sqrt{ }$ & $\sqrt{ }$ \\
\hline
\end{tabular}




\begin{tabular}{|c|c|c|c|}
\hline $\begin{array}{l}\text { Immobilization, knee joint using splinting device [e.g. } \\
\text { supportive and corrective] }\end{array}$ & $\sqrt{ }$ & $\sqrt{ }$ & $\sqrt{ }$ \\
\hline Immobilization, shoulder joint using sling & $\sqrt{ }$ & $\sqrt{ }$ & $\sqrt{ }$ \\
\hline $\begin{array}{l}\text { Implantation of internal device, stomach of gastric tube [e.g. } \\
\text { nasogastric feeding tube] using per orifice approach }\end{array}$ & $\sqrt{ }$ & & \\
\hline $\begin{array}{l}\text { Implantation of internal device, vein NEC of intravenous } \\
\text { catheter using percutaneous approach }\end{array}$ & $\sqrt{ }$ & $\sqrt{ }$ & $\sqrt{ }$ \\
\hline $\begin{array}{l}\text { Management of internal device, bladder of catheter using per } \\
\text { orifice approach }\end{array}$ & $\sqrt{ }$ & & $\sqrt{ }$ \\
\hline $\begin{array}{l}\text { Management of internal device, stomach of percutaneously } \\
\text { inserted gastric tube [PEG] }\end{array}$ & $\sqrt{ }$ & & \\
\hline $\begin{array}{l}\text { Oxygenation, respiratory system NEC using bulk storage } \\
\text { manifold system }\end{array}$ & $\sqrt{ }$ & & \\
\hline $\begin{array}{l}\text { Pharmacotherapy (local), circulatory system NEC } \\
\text { percutaneous infusion approach of electrolyte balance agents }\end{array}$ & $\sqrt{ }$ & & \\
\hline $\begin{array}{l}\text { Pharmacotherapy (local), rectum using per orifice approach } \\
\text { and agent NEC (e.g. oil retention, soap suds) }\end{array}$ & $\sqrt{ }$ & & \\
\hline $\begin{array}{l}\text { Pharmacotherapy (local), respiratory system NEC using } \\
\text { antiasthmatic agent }\end{array}$ & $\sqrt{ }$ & & $\sqrt{ }$ \\
\hline $\begin{array}{l}\text { Pharmacotherapy, total body blood and blood forming organ } \\
\text { agents percutaneous approach [intramuscular, intravenous, } \\
\text { subcutaneous, intradermal] using antithrombotic agent }\end{array}$ & $\sqrt{ }$ & & \\
\hline $\begin{array}{l}\text { Pharmacotherapy, total body general antiinfective agents } \\
\text { percutaneous approach [intramuscular, intravenous, } \\
\text { subcutaneous, intradermal] cephalosporin and related } \\
\text { substance }\end{array}$ & $\sqrt{ }$ & $\sqrt{ }$ & $\sqrt{ }$ \\
\hline $\begin{array}{l}\text { Pharmacotherapy, total body musculoskeletal system agents } \\
\text { percutaneous approach [intramuscular, intravenous, } \\
\text { subcutaneous, intradermal] antiinflammatory and } \\
\text { antirheumatic agent }\end{array}$ & $\sqrt{ }$ & $\sqrt{ }$ & $\sqrt{ }$ \\
\hline $\begin{array}{l}\text { Pharmacotherapy, total body nervous system agents } \\
\text { percutaneous approach [intramuscular, intravenous, } \\
\text { subcutaneous, intradermal] analgesic }\end{array}$ & $\sqrt{ }$ & $\sqrt{ }$ & $\sqrt{ }$ \\
\hline $\begin{array}{l}\text { Reduction, small and large intestine using manual technique } \\
\text { (for hernia reduction alone) }\end{array}$ & $\sqrt{ }$ & & \\
\hline Reduction, wrist joint using closed (external) approach & $\sqrt{ }$ & & \\
\hline Repair, lip using apposition technique [e.g. suture] & $\sqrt{ }$ & & \\
\hline Repair, scalp using apposition technique [e.g. suture, staple] & $\sqrt{ }$ & $\sqrt{ }$ & $\sqrt{ }$ \\
\hline $\begin{array}{l}\text { Repair, scalp using closure device (e.g. clip, adhesive skin } \\
\text { closure [Steri-Strips]) }\end{array}$ & $\sqrt{ }$ & $\sqrt{ }$ & $\sqrt{ }$ \\
\hline $\begin{array}{l}\text { Repair, scalp using glue for apposition (e.g. crazy glue, } \\
\text { glustitch) }\end{array}$ & $\sqrt{ }$ & $\sqrt{ }$ & $\sqrt{ }$ \\
\hline $\begin{array}{l}\text { Repair, skin of abdomen and trunk using open apposition } \\
\text { technique [suture] }\end{array}$ & $\sqrt{ }$ & $\sqrt{ }$ & $\sqrt{ }$ \\
\hline Repair, skin of arm using apposition technique [suture] & $\sqrt{ }$ & $\sqrt{ }$ & $\sqrt{ }$ \\
\hline $\begin{array}{l}\text { Repair, skin of arm using closure device (e.g. clip, adhesive } \\
\text { skin closure [Steri-Strips]) }\end{array}$ & $\sqrt{ }$ & $\sqrt{ }$ & $\sqrt{ }$ \\
\hline Repair, skin of ear using apposition technique [e.g. suture] & $\sqrt{ }$ & & \\
\hline Repair, skin of face using apposition technique [suture] & $\sqrt{ }$ & $\sqrt{ }$ & $\sqrt{ }$ \\
\hline $\begin{array}{l}\text { Repair, skin of face using closure device (e.g. clip, adhesive } \\
\text { skin closure [Steri-Strips]) }\end{array}$ & $\sqrt{ }$ & $\sqrt{ }$ & $\sqrt{ }$ \\
\hline $\begin{array}{l}\text { Repair, skin of face using glue for apposition (e.g. crazy glue } \\
\text { or glustitch) }\end{array}$ & $\sqrt{ }$ & $\sqrt{ }$ & $\sqrt{ }$ \\
\hline Repair, skin of foot using apposition technique [suture] & $\sqrt{ }$ & $\sqrt{ }$ & $\sqrt{ }$ \\
\hline
\end{tabular}


(2)

Diagnostic Interventions

(3)

Diagnostic Imaging Interventions
Repair, skin of forehead using apposition technique [e.g. suturing, stapling]

Repair, skin of forehead using closure device (e.g.clip, adhesive skin closure [Steri-Strips])

Repair, skin of forehead using glue (e.g. crazy glue, glustitch)

Repair, skin of hand using apposition technique [suture]

Repair, skin of hand using closure device (e.g. clip, adhesive

skin closure [Steri-Strips])

Repair, skin of hand using glue for apposition (e.g. crazy glue, glustitch)

Repair, skin of leg using apposition technique [suture]

Repair, skin of leg using closure device (e.g. clip, adhesive skin closure [Steri-Strips])

Repair, skin of nose using apposition technique [e.g. suture]

Assessment (examination), total body general NEC (e.g. multiple reasons)

Electrophysiological measurement, heart NEC external application using recording electrodes (or ECG NOS)

Function study, bladder capacity determination

Function study, bladder post- void residual volume measurement

Function study, respiratory system at rest (steady state)

Inspection, rectum using per orifice manual (digital)

technique

Specimen collection (for diagnostic testing), total body blood

by venous puncture

Ultrasound, abdominal cavity alone

Ultrasound, abdominal cavity transvaginal probe

Ultrasound, arteries of leg NEC with Doppler

Ultrasound, bladder NOS alone

Ultrasound, female genital tract NEC alone

Ultrasound, female genital tract NEC transvaginal approach

Ultrasound, kidney alone

Ultrasound, leg NEC alone

Ultrasound, scrotum alone

Ultrasound, thoracic cavity NEC alone

Ultrasound, veins of arm NEC with Doppler

Ultrasound, veins of leg NEC alone

Ultrasound, veins of leg NEC with color flow and Doppler

Ultrasound, veins of leg NEC with Doppler

Xray, abdominal cavity without contrast (with or without fluoroscopy)

Xray, ankle joint without contrast (e.g. plain film) (with or without fluoroscopy)

Xray, clavicle without contrast (with or without fluoroscopy)

Xray, elbow joint without contrast

Xray, facial bone structure without contrast (e.g. plain film)

Xray, femur without contrast (with or without fluoroscopy)

Xray, foot without contrast (e.g. plain film) (with or without fluoroscopy)

Xray, hand with wrist without contrast (e.g. plain film) (with or without fluoroscopy)

Xray, hip joint without contrast (with or without

\begin{tabular}{|c|c|c|}
\hline$\sqrt{ }$ & $\sqrt{ }$ & $\sqrt{ }$ \\
\hline$\sqrt{ }$ & $\sqrt{ }$ & $\sqrt{ }$ \\
\hline$\sqrt{ }$ & $\sqrt{ }$ & $\sqrt{ }$ \\
\hline$\sqrt{ }$ & $\sqrt{ }$ & $\sqrt{ }$ \\
\hline$\sqrt{ }$ & $\sqrt{ }$ & $\sqrt{ }$ \\
\hline$\sqrt{ }$ & $\sqrt{ }$ & $\sqrt{ }$ \\
\hline$\sqrt{ }$ & $\sqrt{ }$ & $\sqrt{ }$ \\
\hline$\sqrt{ }$ & $\sqrt{ }$ & $\sqrt{ }$ \\
\hline \multicolumn{3}{|c|}{$\sqrt{ }$} \\
\hline$\sqrt{ }$ & $\sqrt{ }$ & $\sqrt{ }$ \\
\hline$\sqrt{ }$ & $\sqrt{ }$ & $\sqrt{ }$ \\
\hline \multicolumn{3}{|c|}{$\sqrt{ }$} \\
\hline$\sqrt{ }$ & $\sqrt{ }$ & $\sqrt{ }$ \\
\hline$\sqrt{ }$ & $\sqrt{ }$ & $\sqrt{ }$ \\
\hline$\sqrt{ }$ & $\sqrt{ }$ & $\sqrt{ }$ \\
\hline$\sqrt{ }$ & $\sqrt{ }$ & $\sqrt{ }$ \\
\hline \multicolumn{3}{|c|}{$\sqrt{ }$} \\
\hline \multicolumn{3}{|c|}{$\sqrt{ }$} \\
\hline \multicolumn{3}{|c|}{$\sqrt{ }$} \\
\hline \multicolumn{3}{|c|}{$\sqrt{ }$} \\
\hline \multicolumn{3}{|c|}{$\sqrt{ }$} \\
\hline \multicolumn{3}{|c|}{$\sqrt{ }$} \\
\hline \multicolumn{3}{|c|}{$\sqrt{ }$} \\
\hline \multicolumn{3}{|c|}{$\sqrt{ }$} \\
\hline \multicolumn{3}{|c|}{$\sqrt{ }$} \\
\hline \multicolumn{3}{|c|}{$\sqrt{ }$} \\
\hline \multicolumn{3}{|c|}{$\sqrt{ }$} \\
\hline \multicolumn{3}{|c|}{$\sqrt{ }$} \\
\hline \multicolumn{3}{|c|}{$\sqrt{ }$} \\
\hline \multicolumn{3}{|c|}{$\sqrt{ }$} \\
\hline \multicolumn{3}{|c|}{$\sqrt{ }$} \\
\hline \multicolumn{3}{|c|}{$\sqrt{ }$} \\
\hline \multicolumn{3}{|c|}{$\sqrt{ }$} \\
\hline \multicolumn{3}{|c|}{$\sqrt{ }$} \\
\hline \multicolumn{3}{|c|}{$\sqrt{ }$} \\
\hline \multicolumn{3}{|c|}{$\sqrt{ }$} \\
\hline \multicolumn{3}{|c|}{$\sqrt{ }$} \\
\hline \multicolumn{3}{|c|}{$\sqrt{ }$} \\
\hline$\sqrt{ }$ & & \\
\hline
\end{tabular}




\begin{tabular}{|c|c|c|c|c|}
\hline & fluoroscopy) & & & \\
\hline & $\begin{array}{l}\text { Xray, humerus without contrast (e.g. plain film) (with or } \\
\text { without fluoroscopy) }\end{array}$ & $\sqrt{ }$ & & \\
\hline & $\begin{array}{l}\text { Xray, joints of fingers and hand NEC without contrast (e.g. } \\
\text { plain film) (with or without fluoroscopy) }\end{array}$ & $\sqrt{ }$ & & \\
\hline & $\begin{array}{l}\text { Xray, kidney with ureter and bladder without contrast (e.g. } \\
\text { plain film KUB) }\end{array}$ & $\sqrt{ }$ & & \\
\hline & $\begin{array}{l}\text { Xray, knee joint without contrast (with or without } \\
\text { fluoroscopy) }\end{array}$ & $\sqrt{ }$ & & \\
\hline & $\begin{array}{l}\text { Xray, lung NEC without contrast (e.g. plain film) (with or } \\
\text { without fluoroscopy) }\end{array}$ & $\sqrt{ }$ & & \\
\hline & $\begin{array}{l}\text { Xray, mandible without contrast (e.g. plain film) (with or } \\
\text { without fluoroscopy) }\end{array}$ & $\sqrt{ }$ & & \\
\hline & $\begin{array}{l}\text { Xray, nose without contrast (e.g. plain film) (with or without } \\
\text { fluoroscopy) }\end{array}$ & $\sqrt{ }$ & & \\
\hline & Xray, pelvis without contrast & $\sqrt{ }$ & & \\
\hline & $\begin{array}{l}\text { Xray, radius and ulna without contrast (e.g. plain film) (with } \\
\text { or without fluoroscopy) }\end{array}$ & $\sqrt{ }$ & & \\
\hline & Xray, ribs without contrast (with or without fluoroscopy) & $\sqrt{ }$ & & \\
\hline & Xray, sacrum and coccyx without contrast & $\sqrt{ }$ & & \\
\hline & $\begin{array}{l}\text { Xray, shoulder joint without contrast (with or without } \\
\text { fluoroscopy) }\end{array}$ & $\sqrt{ }$ & & \\
\hline & $\begin{array}{l}\text { Xray, soft tissue of head and neck without contrast (e.g. plain } \\
\text { film) (with or without fluoroscopy) }\end{array}$ & $\sqrt{ }$ & & \\
\hline & Xray, spinal vertebrae without contrast & $\sqrt{ }$ & & \\
\hline & Xray, sternum without contrast (with or without fluoroscopy) & $\sqrt{ }$ & & \\
\hline & $\begin{array}{l}\text { Xray, thoracic cavity NEC without contrast (with or without } \\
\text { fluoroscopy) }\end{array}$ & $\sqrt{ }$ & & \\
\hline & $\begin{array}{l}\text { Xray, tibia and fibula without contrast (e.g. plain film) (with } \\
\text { or without fluoroscopy) }\end{array}$ & $\sqrt{ }$ & & \\
\hline & $\begin{array}{l}\text { Xray, wrist joint without contrast (e.g. plain film) (with or } \\
\text { without fluoroscopy) }\end{array}$ & $\sqrt{ }$ & & \\
\hline $\begin{array}{l}\text { (6) Cognitive, } \\
\text { Psychosocial }\end{array}$ & $\begin{array}{l}\text { Assessment, mental health and addictions for capacity for } \\
\text { harm (to self or others) }\end{array}$ & $\sqrt{ }$ & $\sqrt{ }$ & $\sqrt{ }$ \\
\hline $\begin{array}{l}\text { and Sensory } \\
\text { Therapeutic }\end{array}$ & $\begin{array}{l}\text { Assessment, mental health and addictions for coping skills } \\
\text { NEC }\end{array}$ & $\sqrt{ }$ & $\sqrt{ }$ & $\sqrt{ }$ \\
\hline Interventions & $\begin{array}{l}\text { Assessment, mental health and addictions for other reason } \\
\text { NEC }\end{array}$ & $\sqrt{ }$ & $\sqrt{ }$ & \\
\hline & Counseling, mental health for substance addiction & $\sqrt{ }$ & $\sqrt{ }$ & $\sqrt{ }$ \\
\hline & Counseling, mental health for behavior & $\sqrt{ }$ & $\sqrt{ }$ & $\sqrt{ }$ \\
\hline & $\begin{array}{l}\text { Counseling, mental health and addictions for concurrent } \\
\text { disorders }\end{array}$ & $\sqrt{ }$ & $\sqrt{ }$ & $\sqrt{ }$ \\
\hline & Counseling, mental health for trauma NEC & $\sqrt{ }$ & $\sqrt{ }$ & $\sqrt{ }$ \\
\hline & $\begin{array}{l}\text { Counseling, mental health for mood (e.g. anger, anxiety, } \\
\text { relaxation, leisure) }\end{array}$ & $\sqrt{ }$ & $\sqrt{ }$ & $\sqrt{ }$ \\
\hline & Counseling, mental health for other reasons & $\sqrt{ }$ & $\sqrt{ }$ & $\sqrt{ }$ \\
\hline & Therapy, mental health crisis/trauma active listening & $\sqrt{ }$ & $\sqrt{ }$ & $\sqrt{ }$ \\
\hline & $\begin{array}{l}\text { Assessment, motor and living skills for activities of daily } \\
\text { living [ADL] }\end{array}$ & $\sqrt{ }$ & $\sqrt{ }$ & $\sqrt{ }$ \\
\hline $\begin{array}{c}\text { (7) Other } \\
\text { Healthcare } \\
\text { Interventions }\end{array}$ & $\begin{array}{l}\text { Counseling, promoting health and preventing disease for } \\
\text { other reason }\end{array}$ & $\sqrt{ }$ & $\sqrt{ }$ & $\sqrt{ }$ \\
\hline $\begin{array}{c}(8) \\
\text { Therapeutic }\end{array}$ & $\begin{array}{l}\text { Immunization (to prevent) diphtheria and tetanus by } \\
\text { intramuscular [IM] injection of toxoid }\end{array}$ & $\sqrt{ }$ & $\sqrt{ }$ & $\sqrt{ }$ \\
\hline
\end{tabular}




\section{Interventions}

Strengthening the Immune

System

Note: CCI = Canadian Classification for Health Interventions, NEC $=$ not elsewhere classified

a Tabular List, 2018 Volume 3

Expert comments highlighted that their selections for healthcare centres were based the underlying assumption that the clinicians of the centres had adequate training and experience with a given intervention. Experts commented that interventions rated for ED suitability only, were largely evaluated that way based on concerns for patient safety if the procedure was unsuccessful. Interventions that did not receive consensus in Round 2 were identified as requiring an element of sedation and a second physician for safety and competence purposes, although this was not agreed upon by all. Some experts emphasized their ratings do not infer any direction for clinical guidance based solely on this study, as an intervention alone does not provide enough specific information to inform care planning without further contextualization.

Experts rated the majority of all interventions as suitable for urgent care centres. Their justification included the urgent care centre's ability to be equipped with the resources required to conduct the interventions (e.g., diagnostic equipment, technicians trained to use the equipment). Comments suggested that walk-in medical centres and nurse practitioner-led clinics may not have access to the same diagnostic imaging recourses, leading experts to deter from selecting these centres as appropriate. Experts did not cite practitioner skill as a limiting factor in rating decisions; however, they did acknowledge some interventions are based on physician or practitioner preference. Some experts recommended there could be other centres that are more appropriate for psychological interventions (e.g., facilities that focus solely on mental health), but were not included in the study. The videoconference held between rounds 1 and 2 contributed insights into nurse practitioner-led clinics receiving more consensus on interventions 
medRxiv preprint doi: https://doi.org/10.1101/2021.06.01.21258191; this version posted June 4, 2021. The copyright holder for this preprint (which was not certified by peer review) is the author/funder, who has granted medRxiv a license to display the preprint in perpetuity.

It is made available under a CC-BY 4.0 International license .

than walk-in medical centres. Experts were also unsure if walk-in centres were staffed with a single clinician, whereas for nurse-practitioner clinics they felt were typically staffed with more than one, which led to an increased comfort with rating interventions that are more timeconsuming or required extended monitoring.

\section{INTERPRETATION}

There is consensus by primary and emergency care physicians on what clinical interventions commonly performed in the ED for non-emergent paramedic transported patients are suitable for alternative sub-acute healthcare settings. Specifically, $68.7 \%$ of included ED interventions were rated as suitable for conduction in urgent care centres, $30.7 \%$ in walk-in medical centres and $31.3 \%$ for nurse-practitioner led clinics, while $2.6 \%$ did not receive consensus.

Our results are consistent with previous literature that suggests urgent care centres and similar sub-acute centres can be reasonable avenues for treatment of non-emergent patient conditions who would otherwise be directed to the ED. $(11,24)$ There is an absence of evidence that measures the appropriateness of which ED interventions could be conducted in sub-acute settings, as most articles analyze patient conditions, diagnostics and medication administration.(11,12,25) Previous literature describes $13.7 \%$ to $27.1 \%$ of all ED patients could be safely managed by urgent care, however do not report which interventions were conducted.(11) Ample literature describes the use of sub-acute centres to offset ED use, however focus heavily on outcomes of patient satisfaction and cost avoidances $(11,24)$, when quality of care, care received and simulation modeling may be more important indicators for supporting paramedics redirection models. $(26,27)$ 
medRxiv preprint doi: https://doi.org/10.1101/2021.06.01.21258191; this version posted June 4, 2021. The copyright holder for this preprint (which was not certified by peer review) is the author/funder, who has granted medRxiv a license to display the preprint in perpetuity.

It is made available under a CC-BY 4.0 International license .

The majority of all included interventions found to be appropriate for sub-acute centres acknowledges the confidence that study experts have in a sub-acute centres ability to conduct emergency department interventions. Of interventions that were rated for ED only, many required sedation practices, intensive monitoring, or advanced emergency physician skills. The four interventions that did not receive consensus all shared the same intervention procedure of using a reduction technique to treat an injury. Of Section 3 interventions involving diagnostic imaging, equipment was determined as the limiting factor (not injury site or physician interpretation).

An overarching goal of our study was to determine if consensus on which ED interventions could be performed elsewhere, such that an epidemiological patient classification could be constructed to inform redirection by paramedics. We recognize that interventions alone are insufficient considerations for such redirection programs. However, in combination with other indicators (e.g., contextualized patient features) and supports (e.g., education), knowledge of interventions suitable for sub-acute healthcare centers will support the construction of a patient classification model for paramedic-initiated redirection from the ED. Future research is required to incorporate additional patient and administrative information into a classification in order to provide contextualization before evaluating its validity for clinical guidance. The results of this study contribute evidence towards informing the circumstances (in part) in which paramedic service-based programs intended to support redirecting ED bound patients may be feasible and appropriate.

\section{LIMITATIONS}


medRxiv preprint doi: https://doi.org/10.1101/2021.06.01.21258191; this version posted June 4, 2021. The copyright holder for this preprint (which was not certified by peer review) is the author/funder, who has granted medRxiv a license to display the preprint in perpetuity.

It is made available under a CC-BY 4.0 International license .

An inherent limitation of using secondary administrative datasets is the completeness of the procedural fields. Our dataset included $63.7 \%$ completeness of the main interventions field in NACRS (1 319388 / 2070 260), to which this is expected as patients admitted to hospital may have their ED interventions recorded in the Discharge Abstract Database as opposed to NACRS. In other instances, there was no intervention completed during the visit, or the intervention was not recorded. Our cohort size remained large and is trustworthy based on our study objectives. Individual judgements may be subjective given an expert's own evaluation with safety in selecting healthcare centres. This limitation was minimized in the study design to include only physicians with adequate knowledge of emergency and primary care practices in Ontario, the Delphi committee contained a high number of experts, and a detailed description of each healthcare centre was provided. The findings of this study may not be generalizable in settings where payment structures for healthcare, accessibility to sub-acute care or ambulance availability are different. Additionally, our research was specific in terms of population (adult, nonemergent, ambulance) and only included ED interventions, without taking into consideration additional clinical details.

\section{CONCLUSION}

With a continued increase in the proportion of non-emergent or low acuity patients transported to EDs by paramedic services, it is important to explore features supporting redirection programs such that their impact on patient and ED utilization outcomes can be examined. A majority of ED interventions conducted by physicians on non-emergent patients transported by paramedic services were identified as suitable for conduction in sub-acute healthcare centres including urgent care centres, in walk-in medical centres and nurse 
practitioner-led clinics. While focusing on interventions alone has limitations, these results suggest there may be a patient population that may be suitable for redirection programs by paramedic services in Ontario as a way of countering the ED crisis. These results may contribute evidence to inform construction of a patient classification system for non-emergent patients for use by paramedic services that (a) could potentially be used to prevent ED visits and (b) better align paramedic services with patient needs. Future research is required to augment our findings with additional patient and hospital contextualization toward such a classification system.

\section{Completing Interests}


None declared.

\section{Acknowledgements}

The authors would like to thank all 20 physicians of the Delphi expert committee who participated in the RAND/UCLA modified Delphi exercise and for their valuable contributions.

\section{Contributions}

RPS and APC led the conceptualization of the study methodology. RPS designed the study, conducted the RAND/UCLA modified Delphi exercise, and drafted and revised the manuscript. WT, AW and LEG made contributions to the design of the study, methods, interpretation and manuscript. All authors critically revised the manuscript, approved the final version and agreed to act as guarantors.

\section{Funding}

The investigators received no specific funding for this study.

\section{Ethics}

This study received a research ethics board exemption waiver from the Hamilton Integrated Research Ethics Board; review reference 2020-11451-GRA.

\section{REFERENCES}


medRxiv preprint doi: https://doi.org/10.1101/2021.06.01.21258191; this version posted June 4, 2021. The copyright holder for this preprint

(which was not certified by peer review) is the author/funder, who has granted medRxiv a license to display the preprint in perpetuity.

It is made available under a CC-BY 4.0 International license .

1. Gill JM. Nonurgent use of the emergency department: appropriate or not? Ann Emerg Med. 1994 Nov;24(5):953-7.

2. Drummond AJ. No room at the inn: overcrowding in Ontario's emergency departments. CJEM. 2002 Mar;4(2):91-7.

3. Strum RP, Tavares W, Worster A, Griffith LE, Rahim A, Costa AP. Development of the PriCARE classification for potentially preventable emergency department visits by ambulance: a RAND/UCLA modified Delphi study protocol. BMJ Open. 2021 Jan 20;11(1):e045351.

4. Institute for Clinical Evaluative Sciences. National Ambulatory Care Reporting System. Toronto, Ontario: IC/ES Central;

5. Under Pressure | Emergency Department Performance in Ontario - Health Quality Ontario [Internet]. [cited $2020 \mathrm{Jul}$ 23]. Available from: http://underpressure.hqontario.ca/

6. Krebs LD, Kirkland SW, Chetram R, Nikel T, Voaklander B, Davidson A, et al. Low-acuity presentations to the emergency department in Canada: exploring the alternative attempts to avoid presentation. Emerg Med J [Internet]. 2017 Apr 1 [cited 2021 Jan 26];34(4):249-55. Available from: https://emj.bmj.com/content/34/4/249

7. Vertesi L. Does the Canadian Emergency Department Triage and Acuity Scale identify nonurgent patients who can be triaged away from the emergency department? CJEM. 2004 Sep;6(5):337-42.

8. Morgan SR, Chang AM, Alqatari M, Pines JM. Non-Emergency Department (ED) Interventions to Reduce ED Utilization: A Systematic Review. Acad Emerg Med [Internet]. 2013 Oct [cited $2021 \mathrm{Feb} 25] ; 20(10): 969-85$. Available from: https://www.ncbi.nlm.nih.gov/pmc/articles/PMC4038086/

9. Morris J, Daoust R, Cournoyer A, Marquis M, Chauny J, Messier A. LO65: Safety and satisfaction of a new program redirecting low-acuity emergency department patients to medical clinic: a prospective cohort study. Canadian Journal of Emergency Medicine [Internet]. 2018 May [cited 2021 Jan 26];20(S1):S29-30. Available from: https://www.cambridge.org/core/journals/canadian-journal-of-emergencymedicine/article/lo65-safety-and-satisfaction-of-a-new-program-redirecting-lowacuityemergency-department-patients-to-medical-clinic-a-prospective-cohortstudy/C4416B685B6E9B710BEBF89BBBAE336E

10. Carlson LC, Raja AS, Dworkis DA, Lee J, Brown DFM, Samuels-Kalow M, et al. Impact of Urgent Care Openings on Emergency Department Visits to Two Academic Medical Centers Within an Integrated Health Care System. Annals of Emergency Medicine [Internet]. 2020 Mar 1 [cited 2021 Jan 26];75(3):382-91. Available from: http://www.sciencedirect.com/science/article/pii/S0196064419305347

11. Weinick RM, Burns RM, Mehrotra A. Many Emergency Department Visits Could Be Managed At Urgent Care Centers And Retail Clinics. Health Affairs [Internet]. 2010 Sep 
medRxiv preprint doi: https://doi.org/10.1101/2021.06.01.21258191; this version posted June 4, 2021. The copyright holder for this preprint

(which was not certified by peer review) is the author/funder, who has granted medRxiv a license to display the preprint in perpetuity.

It is made available under a CC-BY 4.0 International license.

[cited 2020 Nov 14];29(9):1630-6. Available from:

http://www.healthaffairs.org/doi/10.1377/hlthaff.2009.0748

12. Llovera I, Loscalzo K, Gao J, Li T, Brave M, Becker L, et al. Increased access to urgent care centers decreases low acuity diagnoses in a nearby hospital emergency department. The American Journal of Emergency Medicine [Internet]. 2019 Mar [cited 2020 Aug 2];37(3):486-8. Available from: https://linkinghub.elsevier.com/retrieve/pii/S0735675718309318

13. Hutchison B, Østbye T, Barnsley J, Stewart M, Mathews M, Campbell MK, et al. Patient satisfaction and quality of care in walk-in clinics, family practices and emergency departments: the Ontario Walk-In Clinic Study. CMAJ [Internet]. 2003 Apr 15 [cited 2021 Feb 25];168(8):977-83. Available from: https://www.cmaj.ca/content/168/8/977

14. Weel $\mathrm{C}$ van, Kidd MR. Why strengthening primary health care is essential to achieving universal health coverage. CMAJ [Internet]. 2018 Apr 16 [cited $2021 \mathrm{Jan}$ 26];190(15):E463-6. Available from: https://www.cmaj.ca/content/190/15/E463

15. Gonçalves $\square$ Bradley D, Khangura JK, Flodgren G, Perera R, Rowe BH, Shepperd S. Primary care professionals providing non $\square$ urgent care in hospital emergency departments. Cochrane Database of Systematic Reviews [Internet]. 2018 [cited 2021 Jan 30];(2). Available from: https://www.cochranelibrary.com/cdsr/doi/10.1002/14651858.CD002097.pub4/full

16. Silow-Carroll S, Tanya Alteras, Larry Stepnick. Patient-centered care for underserved populations: Definition and best practices. Economic and Social Research Institute; 2008.

17. Tavares W, Drennan I, Van Diepen K, Abanil M, Kedzierski N, Spearen C, et al. Building Capacity in Healthcare by Re-examining Clinical Services in Paramedicine. Prehosp Emerg Care. 2017 Oct;21(5):652-61.

18. Kirkland SW, Soleimani A, Rowe BH, Newton AS. A systematic review examining the impact of redirecting low-acuity patients seeking emergency department care: is the juice worth the squeeze? Emerg Med J [Internet]. 2019 Feb 1 [cited 2021 Jan 26];36(2):97-106. Available from: https://emj.bmj.com/content/36/2/97

19. Fitch K, editor. The Rand/UCLA appropriateness method user's manual. Santa Monica: Rand; 2001. 109 p.

20. Eysenbach G. Improving the Quality of Web Surveys: The Checklist for Reporting Results of Internet E-Surveys (CHERRIES). J Med Internet Res [Internet]. 2004 Sep 29 [cited 2021 Mar 12];6(3). Available from: https://www.ncbi.nlm.nih.gov/pmc/articles/PMC1550605/

21. Murphy, Black, Lamping, McKee, Sanderson, Askham, et al. Consensus development methods, and their use in clinical guideline development. Health Technology Assessment [Internet]. 1998 [cited 2020 Jul 21];2(3). Available from: https://www.journalslibrary.nihr.ac.uk/hta/hta2030 
medRxiv preprint doi: https://doi.org/10.1101/2021.06.01.21258191; this version posted June 4, 2021. The copyright holder for this preprint

(which was not certified by peer review) is the author/funder, who has granted medRxiv a license to display the preprint in perpetuity.

It is made available under a CC-BY 4.0 International license.

22. Sullivan GM. A Primer on the Validity of Assessment Instruments. J Grad Med Educ [Internet]. 2011 Jun [cited 2021 Mar 8];3(2):119-20. Available from:

https://www.ncbi.nlm.nih.gov/pmc/articles/PMC3184912/

23. Canadian Institute for Health Information. Canadian Coding Standards for Version 2018 ICD-10-CA and CCI. CIHI; 2018.

24. Sancton K, Ccfp C, Ccfp LS, Berkowitz J, Mb NS, Ccfp RM. Low-acuity presentations to the emergency department. Canadian Family Physician. 2018;7.

25. Campbell MK, Silver RW, Hoch JS, Østbye T, Stewart M, Barnsley J, et al. Re-utilization outcomes and costs of minor acute illness treated at family physician offices, walk-in clinics, and emergency departments. Canadian Family Physician [Internet]. 2005 Jan 1 [cited 2021 Feb 25];51(1):82-3. Available from: https://www.cfp.ca/content/51/1/82

26. Laskowski M, McLeod RD, Friesen MR, Podaima BW, Alfa AS. Models of Emergency Departments for Reducing Patient Waiting Times. PLOS ONE [Internet]. 2009 Jul 2 [cited $2021 \mathrm{Feb} 25]$; 4(7):e6127. Available from:

https://journals.plos.org/plosone/article?id=10.1371/journal.pone.0006127

27. Laskowski M, Mukhi S. Agent-Based Simulation of Emergency Departments with Patient Diversion. In: Weerasinghe D, editor. Electronic Healthcare. Berlin, Heidelberg: Springer; 2009. p. 25-37. (Lecture Notes of the Institute for Computer Sciences, Social Informatics and Telecommunications Engineering). 


\section{APPENDIX}

Table 4: Intervention consensus of the Delphi expert committee from the modified Delphi exercise, shown as percentages.

\begin{tabular}{|c|c|c|c|c|c|}
\hline \multirow[b]{2}{*}{ Intervention } & \multirow[b]{2}{*}{ CCI Coding } & \multirow{2}{*}{$\begin{array}{c}\text { Acute } \\
\text { ED Only }\end{array}$} & \multicolumn{3}{|c|}{ Sub-Acute } \\
\hline & & & $\mathbf{U C U}$ & FPC & NPC \\
\hline $\begin{array}{l}\text { Control of bleeding, nose using per orifice } \\
\text { approach and agent NEC [e.g. silver nitrate] }\end{array}$ & 1ET13CAZ9 & 5 & 95 & 75 & 70 \\
\hline $\begin{array}{l}\text { Control of bleeding, nose using per orifice } \\
\text { approach and device NEC (e.g. electrocautery)* }\end{array}$ & 1ET13CAGX & 11 & 89 & 28 & 28 \\
\hline $\begin{array}{l}\text { Control of bleeding, nose using per orifice } \\
\text { approach and packing }\end{array}$ & 1ET13CANP & 15 & 85 & 60 & 60 \\
\hline $\begin{array}{l}\text { Drainage, abdominal cavity using percutaneous } \\
\text { (needle) approach }\end{array}$ & 1OT52HA & 70 & 30 & 0 & 0 \\
\hline $\begin{array}{l}\text { Drainage, bladder using per orifice approach } \\
\text { and drainage catheter }\end{array}$ & 1PM52CATS & 5 & 95 & 70 & 65 \\
\hline $\begin{array}{l}\text { Drainage, pleura using percutaneous (needle) } \\
\text { approach }\end{array}$ & 1GV52HA & 85 & 15 & 5 & 5 \\
\hline $\begin{array}{l}\text { Drainage, pleura using percutaneous catheter } \\
\text { (intracostal) with underwater seal drainage } \\
\text { system }\end{array}$ & 1GV52HAHE & 90 & 10 & 5 & 0 \\
\hline $\begin{array}{l}\text { Drainage, stomach using per orifice approach } \\
\text { and mechanical suction pump }\end{array}$ & 1NF52CAQN & 70 & 30 & 5 & 0 \\
\hline $\begin{array}{l}\text { Extraction, rectum using per orifice approach } \\
\text { and manual technique }\end{array}$ & 1NQ57CJ & 5 & 95 & 75 & 80 \\
\hline $\begin{array}{l}\text { Immobilization, knee joint using splinting } \\
\text { device [e.g. supportive and corrective] }\end{array}$ & 1VG03JASR & 0 & 100 & 85 & 75 \\
\hline Immobilization, shoulder joint using sling & 1TA03JASQ & 0 & 100 & 90 & 85 \\
\hline $\begin{array}{l}\text { Implantation of internal device, stomach of } \\
\text { (gastric) tube using percutaneous approach }\end{array}$ & 1NF53HATS & 70 & 30 & 10 & 10 \\
\hline $\begin{array}{l}\text { Implantation of internal device, stomach of } \\
\text { gastric tube [e.g. nasogastric feeding tube] using } \\
\text { per orifice approach* }\end{array}$ & 1NF53CATS & 28 & 72 & 11 & 11 \\
\hline $\begin{array}{l}\text { Implantation of internal device, vein NEC of } \\
\text { intravenous catheter using percutaneous } \\
\text { approach }\end{array}$ & 1KX53HAFT & 0 & 100 & 75 & 80 \\
\hline $\begin{array}{l}\text { Implantation of internal device, vena cava } \\
\text { (superior and inferior) non-tunnelled central } \\
\text { venous catheter using percutaneous transluminal } \\
\text { venous approach }\end{array}$ & 1IS53GRLF & 100 & 0 & 0 & 0 \\
\hline $\begin{array}{l}\text { Management of internal device, bladder of } \\
\text { catheter using per orifice approach }\end{array}$ & 1PM54CATS & 5 & 95 & 60 & 70 \\
\hline $\begin{array}{l}\text { Management of internal device, stomach of } \\
\text { percutaneously inserted gastric tube [PEG] }\end{array}$ & 1NF54HATS & 30 & 70 & 30 & 30 \\
\hline $\begin{array}{l}\text { Oxygenation, respiratory system NEC using } \\
\text { bulk storage manifold system }\end{array}$ & 1GZ32CAMY & 10 & 90 & 55 & 50 \\
\hline $\begin{array}{l}\text { Pharmacotherapy (local), circulatory system } \\
\text { NEC percutaneous infusion approach of } \\
\text { electrolyte balance agents }\end{array}$ & 1LZ35HHC7 & 10 & 90 & 50 & 55 \\
\hline $\begin{array}{l}\text { Pharmacotherapy (local), rectum using per } \\
\text { orifice approach and agent NEC (e.g. oil } \\
\text { retention, soap suds) }\end{array}$ & 1NQ35CAZ9 & 5 & 95 & 60 & 60 \\
\hline
\end{tabular}




\begin{tabular}{|c|c|c|c|c|c|}
\hline $\begin{array}{l}\text { Pharmacotherapy (local), respiratory system } \\
\text { NEC using antiasthmatic agent }\end{array}$ & 1GZ35CAR3 & 5 & 95 & 65 & 75 \\
\hline $\begin{array}{l}\text { Pharmacotherapy, total body blood and blood } \\
\text { forming organ agents percutaneous approach } \\
\text { [intramuscular, intravenous, subcutaneous, } \\
\text { intradermal] using antithrombotic agent }\end{array}$ & 1ZZ35HAC1 & 20 & 80 & 50 & 65 \\
\hline $\begin{array}{l}\text { Pharmacotherapy, total body general } \\
\text { antiinfective agents percutaneous approach } \\
\text { [intramuscular, intravenous, subcutaneous, } \\
\text { intradermal] cephalosporin and related } \\
\text { substance }\end{array}$ & 1ZZ35HAK4 & 0 & 100 & 80 & 90 \\
\hline $\begin{array}{l}\text { Pharmacotherapy, total body musculoskeletal } \\
\text { system agents percutaneous approach } \\
\text { [intramuscular, intravenous, subcutaneous, } \\
\text { intradermal] antiinflammatory and } \\
\text { antirheumatic agent }\end{array}$ & 1ZZ35HAN1 & 0 & 100 & 85 & 90 \\
\hline $\begin{array}{l}\text { Pharmacotherapy, total body nervous system } \\
\text { agents percutaneous approach [intramuscular, } \\
\text { intravenous, subcutaneous, intradermal] } \\
\text { analgesic }\end{array}$ & 1ZZ35HAP2 & 0 & 100 & 80 & 95 \\
\hline $\begin{array}{l}\text { Reduction, ankle joint using closed (external) } \\
\text { approach }^{+}\end{array}$ & 1WA73JA & 50 & 50 & 0 & 0 \\
\hline $\begin{array}{l}\text { Reduction, elbow joint using closed (external) } \\
\text { approach }^{+}\end{array}$ & 1TM73JA & 50 & 50 & 0 & 0 \\
\hline $\begin{array}{l}\text { Reduction, hip joint using closed (external) } \\
\text { approach* }\end{array}$ & 1VA73JA & 72 & 28 & 0 & 0 \\
\hline $\begin{array}{l}\text { Reduction, radius and ulna using closed } \\
\text { (external) approach }\end{array}$ & 1TV73JA & 67 & 33 & 0 & 0 \\
\hline $\begin{array}{l}\text { Reduction, small and large intestine using } \\
\text { manual technique (for hernia reduction alone) }\end{array}$ & 1NP73JH & 30 & 70 & 45 & 35 \\
\hline $\begin{array}{l}\text { Reduction, tibia and fibula using closed } \\
\text { (external) approach }\end{array}$ & 1VQ73JA & 67 & 33 & 0 & 0 \\
\hline $\begin{array}{l}\text { Reduction, wrist joint using closed (external) } \\
\text { approach* }\end{array}$ & 1UB73JA & 28 & 72 & 0 & 0 \\
\hline $\begin{array}{l}\text { Repair, lip using apposition technique [e.g. } \\
\text { suture] }\end{array}$ & 1YE80LA & 5 & 95 & 50 & 50 \\
\hline $\begin{array}{l}\text { Repair, scalp using apposition technique [e.g. } \\
\text { suture, staple] }\end{array}$ & 1YA80LA & 0 & 100 & 90 & 95 \\
\hline $\begin{array}{l}\text { Repair, scalp using closure device (e.g. clip, } \\
\text { adhesive skin closure [Steri-Strips]) }\end{array}$ & 1YA80JAFF & 0 & 100 & 90 & 95 \\
\hline $\begin{array}{l}\text { Repair, scalp using glue for apposition (e.g. } \\
\text { crazy glue, glustitch) }\end{array}$ & 1YA80LAW4 & 0 & 100 & 90 & 95 \\
\hline $\begin{array}{l}\text { Repair, skin of abdomen and trunk using open } \\
\text { apposition technique [suture] }\end{array}$ & 1YS80LA & 5 & 95 & 80 & 80 \\
\hline $\begin{array}{l}\text { Repair, skin of arm using apposition technique } \\
\text { [suture] }\end{array}$ & 1YT80LA & 5 & 95 & 85 & 90 \\
\hline $\begin{array}{l}\text { Repair, skin of arm using closure device (e.g. } \\
\text { clip, adhesive skin closure [Steri-Strips]) }\end{array}$ & 1YT80JAFF & 5 & 95 & 85 & 90 \\
\hline $\begin{array}{l}\text { Repair, skin of ear using apposition technique } \\
\text { [e.g. suture] }\end{array}$ & 1YC80LA & 15 & 85 & 35 & 25 \\
\hline $\begin{array}{l}\text { Repair, skin of face using apposition technique } \\
\text { [suture] }\end{array}$ & 1YF80LA & 15 & 85 & 70 & 70 \\
\hline $\begin{array}{l}\text { Repair, skin of face using closure device (e.g. } \\
\text { clip, adhesive skin closure [Steri-Strips]) }\end{array}$ & 1YF80JAFF & 15 & 85 & 70 & 70 \\
\hline Repair, skin of face using glue for apposition & 1YF80LAW4 & 15 & 85 & 70 & 70 \\
\hline
\end{tabular}




\begin{tabular}{|c|c|c|c|c|c|}
\hline (e.g. crazy glue or glustitch) & & & & & \\
\hline $\begin{array}{l}\text { Repair, skin of foot using apposition technique } \\
\text { [suture] }\end{array}$ & 1YW80LA & 5 & 95 & 85 & 85 \\
\hline $\begin{array}{l}\text { Repair, skin of forehead using apposition } \\
\text { technique [e.g. suturing, stapling] }\end{array}$ & 1YB80LA & 10 & 90 & 70 & 75 \\
\hline $\begin{array}{l}\text { Repair, skin of forehead using closure device } \\
\text { (e.g.clip, adhesive skin closure [Steri-Strips]) }\end{array}$ & 1YB80JAFF & 0 & 100 & 80 & 85 \\
\hline $\begin{array}{l}\text { Repair, skin of forehead using glue (e.g. crazy } \\
\text { glue, glustitch) }\end{array}$ & 1YB80LAW4 & 0 & 100 & 80 & 85 \\
\hline $\begin{array}{l}\text { Repair, skin of hand using apposition technique } \\
\text { [suture] }\end{array}$ & 1YU80LA & 0 & 100 & 85 & 75 \\
\hline $\begin{array}{l}\text { Repair, skin of hand using closure device (e.g. } \\
\text { clip, adhesive skin closure [Steri-Strips]) }\end{array}$ & 1YU80JAFF & 0 & 100 & 85 & 75 \\
\hline $\begin{array}{l}\text { Repair, skin of hand using glue for apposition } \\
\text { (e.g. crazy glue, glustitch) }\end{array}$ & 1YU80LAW4 & 0 & 100 & 85 & 75 \\
\hline $\begin{array}{l}\text { Repair, skin of leg using apposition technique } \\
\text { [suture] }\end{array}$ & 1YV80LA & 0 & 100 & 85 & 85 \\
\hline $\begin{array}{l}\text { Repair, skin of leg using closure device (e.g. } \\
\text { clip, adhesive skin closure [Steri-Strips]) }\end{array}$ & 1YV80JAFF & 0 & 100 & 85 & 85 \\
\hline $\begin{array}{l}\text { Repair, skin of nose using apposition technique } \\
\text { [e.g. suture] }\end{array}$ & 1YD80LA & 10 & 90 & 45 & 45 \\
\hline $\begin{array}{l}\text { Stimulation, heart NEC external approach using } \\
\text { electrode with synchronized DC shock* }\end{array}$ & 1HZ09JAJF & 89 & 11 & 6 & 0 \\
\hline $\begin{array}{l}\text { Ventilation, respiratory system NEC invasive } \\
\text { per orifice approach by (endotracheal) } \\
\text { intubation and positive pressure (e.g. CPAP, } \\
\text { BIPAP, IPPV)* }\end{array}$ & 1GZ31CAND & 89 & 11 & 0 & 0 \\
\hline $\begin{array}{l}\text { Ventilation, respiratory system NEC non- } \\
\text { invasive approach and positive pressure } \\
\text { ventilation (e.g. CPAP, BIPAP, IPPV)** }\end{array}$ & 1GZ31CBND & 89 & 11 & 0 & 0 \\
\hline $\begin{array}{l}\text { Assessment (examination), total body general } \\
\text { NEC (e.g. multiple reasons) }\end{array}$ & $2 \mathrm{ZZ02ZZ}$ & 0 & 100 & 95 & 90 \\
\hline $\begin{array}{l}\text { Electrophysiological measurement, heart NEC } \\
\text { external application using recording electrodes } \\
\text { (or ECG NOS) }\end{array}$ & 2HZ24JAXJ & 0 & 100 & 85 & 85 \\
\hline Function study, bladder capacity determination & 2PM58VE & 20 & 80 & 65 & 65 \\
\hline $\begin{array}{l}\text { Function study, bladder post- void residual } \\
\text { volume measurement }\end{array}$ & 2PM58VD & 10 & 90 & 75 & 75 \\
\hline $\begin{array}{l}\text { Function study, respiratory system at rest } \\
\text { (steady state) }\end{array}$ & 2GZ58TA & 5 & 95 & 85 & 85 \\
\hline $\begin{array}{l}\text { Inspection, rectum using per orifice manual } \\
\text { (digital) technique }\end{array}$ & 2NQ70CA & 0 & 100 & 100 & 100 \\
\hline $\begin{array}{l}\text { Specimen collection (diagnostic), spinal canal } \\
\text { and meninges using percutaneous (needle) } \\
\text { approach }\end{array}$ & 2AX13HA & 80 & 20 & 5 & 5 \\
\hline $\begin{array}{l}\text { Specimen collection (for diagnostic testing), } \\
\text { total body blood by venous puncture }\end{array}$ & 2ZZ13RA & 0 & 100 & 90 & 90 \\
\hline $\begin{array}{l}\text { Computerized tomography }[\mathrm{CT}] \text {, abdominal } \\
\text { arteries NEC with contrast }\end{array}$ & 3KE20WC & 75 & 25 & 0 & 0 \\
\hline $\begin{array}{l}\text { Computerized tomography }[\mathrm{CT}] \text {, abdominal } \\
\text { cavity with contrast }\end{array}$ & 3OT20WC & 75 & 25 & 0 & 0 \\
\hline $\begin{array}{l}\text { Computerized tomography }[\mathrm{CT}] \text {, abdominal } \\
\text { cavity without contrast }\end{array}$ & 3OT20VA & 75 & 25 & 0 & 0 \\
\hline $\begin{array}{l}\text { Computerized tomography [CT], abdominal } \\
\text { cavity without enhancement (contrast) }\end{array}$ & 3OT20WA & 75 & 25 & 0 & 0 \\
\hline
\end{tabular}




\begin{tabular}{|c|c|c|c|c|c|}
\hline $\begin{array}{l}\text { Computerized tomography [CT], arm NEC } \\
\text { without contrast }\end{array}$ & 3TZ20VA & 75 & 25 & 0 & 0 \\
\hline $\begin{array}{l}\text { Computerized tomography [CT], brain with and } \\
\text { without enhancement (contrast) }\end{array}$ & 3AN20WE & 80 & 20 & 0 & 0 \\
\hline $\begin{array}{l}\text { Computerized tomography }[\mathrm{CT}] \text {, brain with } \\
\text { contrast }\end{array}$ & 3AN20WC & 80 & 20 & 0 & 0 \\
\hline $\begin{array}{l}\text { Computerized tomography }[\mathrm{CT}] \text {, brain without } \\
\text { contrast }\end{array}$ & 3AN20VA & 80 & 20 & 0 & 0 \\
\hline $\begin{array}{l}\text { Computerized tomography }[\mathrm{CT}] \text {, brain without } \\
\text { enhancement (contrast) }\end{array}$ & 3AN20WA & 80 & 20 & 0 & 0 \\
\hline $\begin{array}{l}\text { Computerized tomography }[\mathrm{CT}] \text {, carotid artery } \\
\text { with contrast }\end{array}$ & 3JE20WC & 75 & 25 & 0 & 0 \\
\hline $\begin{array}{l}\text { Computerized tomography [CT], head NEC } \\
\text { with contrast }\end{array}$ & 3ER20WC & 80 & 20 & 0 & 0 \\
\hline $\begin{array}{l}\text { Computerized tomography [CT], head NEC } \\
\text { without contrast }\end{array}$ & 3ER20VA & 80 & 20 & 0 & 0 \\
\hline $\begin{array}{l}\text { Computerized tomography [CT], head NEC } \\
\text { without enhancement (contrast) }\end{array}$ & 3ER20WA & 80 & 20 & 0 & 0 \\
\hline $\begin{array}{l}\text { Computerized tomography }[\mathrm{CT}] \text {, kidney } \\
\text { without contrast }\end{array}$ & 3PC20VA & 75 & 25 & 0 & 0 \\
\hline $\begin{array}{l}\text { Computerized tomography [CT], kidney } \\
\text { without enhancement (contrast) }\end{array}$ & 3PC20WA & 75 & 25 & 0 & 0 \\
\hline $\begin{array}{l}\text { Computerized tomography [CT], leg NEC } \\
\text { without contrast }\end{array}$ & 3VZ20VA & 75 & 25 & 0 & 0 \\
\hline $\begin{array}{l}\text { Computerized Tomography [CT], leg NEC } \\
\text { without enhancement (contrast) }\end{array}$ & 3VZ20WA & 75 & 25 & 0 & 0 \\
\hline $\begin{array}{l}\text { Computerized tomography [CT], lung NEC } \\
\text { with contrast }\end{array}$ & 3GT20WC & 80 & 20 & 0 & 0 \\
\hline $\begin{array}{l}\text { Computerized tomography [CT], } \\
\text { musculoskeletal system NEC without contrast }\end{array}$ & 3WZ20VA & 75 & 25 & 0 & 0 \\
\hline $\begin{array}{l}\text { Computerized tomography [CT], other vessels } \\
\text { of head, neck and spine NEC with contrast }\end{array}$ & 3JX20WC & 80 & 20 & 0 & 0 \\
\hline $\begin{array}{l}\text { Computerized tomography [CT], soft tissue of } \\
\text { neck with contrast }\end{array}$ & 3FY20WC & 75 & 25 & 0 & 0 \\
\hline $\begin{array}{l}\text { Computerized tomography [CT], spinal } \\
\text { vertebrae without contrast }\end{array}$ & 3SC20VA & 80 & 20 & 0 & 0 \\
\hline $\begin{array}{l}\text { Computerized tomography [CT], spinal } \\
\text { vertebrae without enhancement (contrast) }\end{array}$ & 3SC20WA & 80 & 20 & 0 & 0 \\
\hline $\begin{array}{l}\text { Computerized tomography }[\mathrm{CT}] \text {, thoracic cavity } \\
\text { NEC without contrast }\end{array}$ & 3GY20VA & 75 & 25 & 0 & 0 \\
\hline $\begin{array}{l}\text { Computerized tomography [CT], total body } \\
\text { without contrast }\end{array}$ & 3ZZ20VA & 75 & 25 & 0 & 0 \\
\hline $\begin{array}{l}\text { Computerized tomography [CT], total body } \\
\text { with contrast }\end{array}$ & 3ZZ20WC & 75 & 25 & 0 & 0 \\
\hline $\begin{array}{l}\text { Computerized tomography }[\mathrm{CT}] \text {, urinary system } \\
\text { NEC without contrast }\end{array}$ & 3PZ20VA & 85 & 15 & 0 & 0 \\
\hline $\begin{array}{l}\text { Computerized tomography thoracic cavity NEC } \\
\text { with contrast }\end{array}$ & 3GY20WC & 75 & 25 & 0 & 0 \\
\hline $\begin{array}{l}\text { Computerized tomography thoracic cavity NEC } \\
\text { without enhancement (contrast) }\end{array}$ & 3GY20WA & 75 & 25 & 0 & 0 \\
\hline $\begin{array}{l}\text { Computerized tomography, thoracic vessels } \\
\text { NEC with contrast }\end{array}$ & 3JY20WC & 75 & 25 & 0 & 0 \\
\hline $\begin{array}{l}\text { Magnetic resonance imaging [MRI], spinal } \\
\text { vertebrae without contrast }\end{array}$ & 3SC40VA & 90 & 10 & 0 & 0 \\
\hline Magnetic resonance imaging [MRI], spinal & 3SC40WA & 90 & 10 & 0 & 0 \\
\hline
\end{tabular}




\begin{tabular}{|c|c|c|c|c|c|}
\hline vertebrae without enhancement & & & & & \\
\hline Ultrasound, abdominal cavity alone & 3OT30DA & 5 & 95 & 50 & 35 \\
\hline $\begin{array}{l}\text { Ultrasound, abdominal cavity transvaginal } \\
\text { probe }\end{array}$ & 3OT30LA & 20 & 80 & 45 & 30 \\
\hline Ultrasound, arteries of leg NEC with Doppler & 3KG30DC & 20 & 80 & 45 & 25 \\
\hline Ultrasound, bladder NOS alone & 3PM30DA & 10 & 90 & 50 & 35 \\
\hline Ultrasound, female genital tract NEC alone & 3RZ30DA & 15 & 85 & 45 & 35 \\
\hline $\begin{array}{l}\text { Ultrasound, female genital tract NEC } \\
\text { transvaginal approach }\end{array}$ & 3RZ30LA & 20 & 80 & 45 & 30 \\
\hline Ultrasound, kidney alone & 3PC30DA & 15 & 85 & 45 & 25 \\
\hline Ultrasound, leg NEC alone & 3VZ30DA & 20 & 80 & 45 & 30 \\
\hline Ultrasound, scrotum alone & 3QG30DA & 25 & 75 & 35 & 20 \\
\hline Ultrasound, thoracic cavity NEC alone & 3GY30DA & 15 & 85 & 35 & 25 \\
\hline Ultrasound, veins of arm NEC with Doppler & 3JU30DC & 20 & 80 & 45 & 30 \\
\hline Ultrasound, veins of leg NEC alone & 3KR30DA & 15 & 85 & 45 & 30 \\
\hline $\begin{array}{l}\text { Ultrasound, veins of leg NEC with color flow } \\
\text { and Doppler }\end{array}$ & 3KR30DC & 15 & 85 & 45 & 30 \\
\hline Ultrasound, veins of leg NEC with Doppler & 3KR30DD & 15 & 85 & 45 & 30 \\
\hline $\begin{array}{l}\text { Xray, abdominal cavity without contrast (with } \\
\text { or without fluoroscopy) }\end{array}$ & 3OT10VA & 0 & 100 & 0 & 0 \\
\hline $\begin{array}{l}\text { Xray, ankle joint without contrast (e.g. plain } \\
\text { film) (with or without fluoroscopy) }\end{array}$ & 3WA10VA & 0 & 100 & 0 & 0 \\
\hline $\begin{array}{l}\text { Xray, clavicle without contrast (with or without } \\
\text { fluoroscopy) }\end{array}$ & 3SM10VA & 0 & 100 & 0 & 0 \\
\hline Xray, elbow joint without contrast & 3TM10VA & 0 & 100 & 0 & 0 \\
\hline $\begin{array}{l}\text { Xray, facial bone structure without contrast (e.g. } \\
\text { plain film) }\end{array}$ & 3EI10VA & 10 & 90 & 0 & 0 \\
\hline $\begin{array}{l}\text { Xray, femur without contrast (with or without } \\
\text { fluoroscopy) }\end{array}$ & $3 \mathrm{VC} 10 \mathrm{VA}$ & 0 & 100 & 0 & 0 \\
\hline $\begin{array}{l}\text { Xray, foot without contrast (e.g. plain film) } \\
\text { (with or without fluoroscopy) }\end{array}$ & 3WG10VA & 5 & 95 & 0 & 0 \\
\hline $\begin{array}{l}\text { Xray, hand with wrist without contrast (e.g. } \\
\text { plain film) (with or without fluoroscopy) }\end{array}$ & 3UZ10VA & 5 & 95 & 0 & 0 \\
\hline $\begin{array}{l}\text { Xray, hip joint without contrast (with or without } \\
\text { fluoroscopy) }\end{array}$ & 3VA10VA & 5 & 95 & 0 & 0 \\
\hline $\begin{array}{l}\text { Xray, humerus without contrast (e.g. plain film) } \\
\text { (with or without fluoroscopy) }\end{array}$ & 3TK10VA & 0 & 100 & 0 & 0 \\
\hline $\begin{array}{l}\text { Xray, joints of fingers and hand NEC without } \\
\text { contrast (e.g. plain film) (with or without } \\
\text { fluoroscopy) }\end{array}$ & 3UL10VA & 5 & 95 & 0 & 0 \\
\hline $\begin{array}{l}\text { Xray, kidney with ureter and bladder without } \\
\text { contrast (e.g. plain film KUB) }\end{array}$ & 3PS10VA & 10 & 90 & 0 & 0 \\
\hline $\begin{array}{l}\text { Xray, knee joint without contrast (with or } \\
\text { without fluoroscopy) }\end{array}$ & 3VG10VA & 5 & 95 & 0 & 0 \\
\hline $\begin{array}{l}\text { Xray, lung NEC without contrast (e.g. plain } \\
\text { film) (with or without fluoroscopy) }\end{array}$ & 3GT10VA & 0 & 100 & 0 & 0 \\
\hline $\begin{array}{l}\text { Xray, mandible without contrast (e.g. plain } \\
\text { film) (with or without fluoroscopy) }\end{array}$ & 3EE10VA & 10 & 90 & 0 & 0 \\
\hline $\begin{array}{l}\text { Xray, nose without contrast (e.g. plain film) } \\
\text { (with or without fluoroscopy) }\end{array}$ & 3ET10VA & 5 & 95 & 0 & 0 \\
\hline Xray, pelvis without contrast & 3SQ10VA & 5 & 95 & 0 & 0 \\
\hline $\begin{array}{l}\text { Xray, radius and ulna without contrast (e.g. } \\
\text { plain film) (with or without fluoroscopy) }\end{array}$ & 3TV10VA & 5 & 95 & 0 & 0 \\
\hline Xray, ribs without contrast (with or without & 3SL10VA & 5 & 95 & 0 & 0 \\
\hline
\end{tabular}


medRxiv preprint doi: https://doi.org/10.1101/2021.06.01.21258191; this version posted June 4, 2021. The copyright holder for this preprint (which was not certified by peer review) is the author/funder, who has granted medRxiv a license to display the preprint in perpetuity.

It is made available under a CC-BY 4.0 International license .

\begin{tabular}{|c|c|c|c|c|c|}
\hline fluoroscopy) & & & & & \\
\hline Xray, sacrum and coccyx without contrast & 3SF10VA & 5 & 95 & 0 & 0 \\
\hline $\begin{array}{l}\text { Xray, shoulder joint without contrast (with or } \\
\text { without fluoroscopy) }\end{array}$ & 3TA10VA & 5 & 95 & 0 & 0 \\
\hline $\begin{array}{l}\text { Xray, soft tissue of head and neck without } \\
\text { contrast (e.g. plain film) (with or without } \\
\text { fluoroscopy) }\end{array}$ & 3EQ10VA & 5 & 95 & 0 & 0 \\
\hline Xray, spinal vertebrae without contrast & 3SC10VA & 5 & 95 & 0 & 0 \\
\hline $\begin{array}{l}\text { Xray, sternum without contrast (with or without } \\
\text { fluoroscopy) }\end{array}$ & 3SK10VA & 5 & 95 & 0 & 0 \\
\hline $\begin{array}{l}\text { Xray, thoracic cavity NEC without contrast } \\
\text { (with or without fluoroscopy) }\end{array}$ & 3GY10VA & 5 & 95 & 0 & 0 \\
\hline $\begin{array}{l}\text { Xray, tibia and fibula without contrast (e.g. } \\
\text { plain film) (with or without fluoroscopy) }\end{array}$ & 3VQ10VA & 5 & 95 & 0 & 0 \\
\hline $\begin{array}{l}\text { Xray, wrist joint without contrast (e.g. plain } \\
\text { film) (with or without fluoroscopy) }\end{array}$ & 3UB10VA & 5 & 95 & 0 & 0 \\
\hline $\begin{array}{l}\text { Assessment, mental health and addictions for } \\
\text { capacity for harm (to self or others) }\end{array}$ & 6АA02CP & 15 & 85 & 80 & 80 \\
\hline $\begin{array}{l}\text { Assessment, mental health and addictions for } \\
\text { coping skills NEC }\end{array}$ & 6AA02SK & 10 & 90 & 85 & 85 \\
\hline $\begin{array}{l}\text { Assessment, mental health and addictions for } \\
\text { other reason NEC }\end{array}$ & 6AA02ZZ & 15 & 85 & 80 & 60 \\
\hline $\begin{array}{l}\text { Counseling, mental health for substance } \\
\text { addiction }\end{array}$ & 6AA10AD & 5 & 95 & 90 & 90 \\
\hline Counseling, mental health for behavior & 6AA10BE & 5 & 95 & 90 & 70 \\
\hline $\begin{array}{l}\text { Counseling, mental health and addictions for } \\
\text { concurrent disorders }\end{array}$ & 6AA10CD & 5 & 95 & 90 & 85 \\
\hline Counseling, mental health for trauma NEC & 6AA10CT & 10 & 90 & 80 & 75 \\
\hline $\begin{array}{l}\text { Counseling, mental health for mood (e.g. anger, } \\
\text { anxiety, relaxation, leisure) }\end{array}$ & 6AA10MA & 10 & 90 & 90 & 80 \\
\hline Counseling, mental health for other reasons & 6AA10ZZ & 10 & 90 & 90 & 75 \\
\hline $\begin{array}{l}\text { Therapy, mental health crisis/trauma active } \\
\text { listening }\end{array}$ & 6АA30СТАA & 10 & 90 & 95 & 90 \\
\hline $\begin{array}{l}\text { Assessment, motor and living skills for } \\
\text { activities of daily living [ADL] }\end{array}$ & 6VA02ZZ & 5 & 95 & 95 & 90 \\
\hline $\begin{array}{l}\text { Counseling, promoting health and preventing } \\
\text { disease for other reason }\end{array}$ & 7SP10ZZ & 5 & 100 & 100 & 95 \\
\hline $\begin{array}{l}\text { Immunization (to prevent) diphtheria and } \\
\text { tetanus by intramuscular [IM] injection of } \\
\text { toxoid }\end{array}$ & 8МK70НАBК & 0 & 100 & 100 & 100 \\
\hline
\end{tabular}

